\title{
Gender Performance, Sexual Subjects and International Law
}

\author{
Brenda Cossman
}

Version Publisher's Version

Citation Brenda Cossman, "Gender Performance, Sexual Subjects and

(published version) International Law" (2002) 15 Canadian Journal of Law and Jurisprudence 281 .

Publisher's Statement This article has been published in a revised form in the Canadian Journal of Law and Jurisprudence. https://doi.org/10.1017/s0841820900003623 This version is free to view and download for private research and study only. Not for redistribution, re-sale or use in derivative works. (C) Cambridge University Press.

Always cite the published version, so the author(s) will receive recognition through services that track citation counts, e.g. Scopus. If you need to cite the page number of the author manuscript from TSpace because you cannot access the published version, then cite the TSpace version in addition to the published version using the permanent URI (handle) found on the record page.

This article was made openly accessible by $U$ of $T$ Faculty. Please tell us how this access benefits you. Your story matters. 


\section{Gender Performance, Sexual Subjects and International Law}

\section{Brenda Cossman}

In Shakespeare in Love, Gwyneth Paltrow's performance as Viola, the object of Will's affection, includes an interesting twist on the cross-dressing norm of Renaissance theatre. The drama of the movie unfolds in and around drama-the production of Shakespeare's first blockbuster, Romeo and Juliet. In a small gesture of gender bending, Viola's love life unfolds as Juliet, while she performs Romeo on stage. But, Viola's performance as Romeo is prefigured by her performance as an actor-an all male cast in Elizabethan times. Her identity as an actor is thus already a performance - a gender performance in which the first test of her acting skills is her ability to pass as a man. Viola's "real" identity is eventually discovered, the theatrical production threatened, and only through the Queen's intentional suspension of disbelief is Viola allowed to perform, ultimately as Juliet. It is a lighthearted tale of permissible and impermissible cross-dressing of young men performing female roles, and of young women acting as men in order to perform at all.'

I start with Paltrow's performance in order to tell a story about gender, or more specifically, a story about the meaning of gender in discussions of the gender of international law. I use it to introduce and explore the implications of a methodological approach to gender, based on performance and performativity, that is, the idea that gender is not something one has, but something one does, it is neither a self-evident noun nor adjective, but a verb. ${ }^{2}$ In international law, to the extent that feminist scholarship and activism has have succeeded in getting gender on the agenda at all, the understanding of gender and its relationship to sex remains fairly traditional. Gender continues to be a category related in some fundamental way to sex. Gender is the social meaning given to the biological differences of sex. In this, sex, then, continues to operate as the biological and natural differences of male and female bodies.

This common sense story of sex/gender has been troubled in recent years by a range of feminist theory. From Judith Butler's groundbreaking theory of gender performance, to the explosion of feminist interrogation of the body, the so-called natural or biological body has been recast as an already discursively and culturally prefigured body. In this paper, I explore the subversive possibilities of this troubling

\footnotetext{
I am grateful for the helpful comments of Karen Knopp, Ed Morgan and Kerry Rittich. This paper was originally presented at the Gender of International Law panel at the American Society of International Law Annual Meetings, Washington D.C., March 1999.

1. On the role of cross-dressing in Renaissance theatre, and Shakespearean theatre in particular, see Marjorie Garber, Vested Interests: Cross-Dressing and Cultural Anxiety (New York: Harper Perennial, 1993).

2. Judith Butler, Gender Trouble: Feminism and the Subversion of Identity (New York: Routledge, 1990) [hereinafter Gender Trouble], and Bodies that Matter: On the Discursive Limits of 'Sex' (New York: Routledge, 1993) [hereinafter Bodies that Matter].
} 
of the sex/gender story for international law. I argue that such a troubling of the sex/gender story, and a methodological approach to gender informed, at least in part by the idea of performativity, may create space for a range of marginalized subjects and gender outlaws within the terrain of the international.

\section{Gender as Performance}

Judith Butler sets out to disrupt the pervasive understanding of gender as the cultural interpretation of sex, arguing instead that the underlying category of sex is neither natural nor biologically determined, but rather, is itself discursively produced in and through gender. ${ }^{3}$ Butler argues that gender is performative-a doing and constituting of the identity that it is purported to be.

As in other ritual social dramas, the action of gender requires a performance that is repeated. This repetition is at once a reenactment and a reexperiencing of a set of meanings already socially established; and it is the mundane and ritualized form of their legitimation. ${ }^{4}$

According to Butler, "gender ought not to be constructed as a stable identity or locus of agency", but rather, should be understood as "an identity tenuously constituted in time, instituted in an exterior space through a stylized repetition of acts".

Within this performative theory of gender, Butler argues that gender is part of the very apparatus by which sex is produced and then rendered "prediscursive"" or "natural". Gender, according to Butler, is then all about the production of sex, constructing sex through a ritualized repetition of norms. It produces the very binaries of male and female sex that it is said to reflect, binaries produced in and through a dominant heterosexual matrix. The bodies that make sense are those presented as reflecting a stable sex, expressed through a stable gender that is oppositional and hierarchical, defined in and through the practice of heterosexuality.

The category of "sex" is, from the start, normative; it is what Foucault has called a "'regulatory ideal" In this senses, then, "sex" not only functions as a norm, but is part of a regulatory practice that produces the bodies it governs, that is, whose regulatory force is made clear as a kind of productive power, the power to produce-demarcate, circulate, differentiate-the bodies it controls. ${ }^{6}$

An important part of Butler's objective is to trouble and challenge the inevitability of the relationship between sex and gender, as well as desire and sexual practice, and to explore the possibilities of alternative identities-that is, identities in which alternative gendered identities are imagined and performed. The idea is not that as a performance, gender can simply be performed differently - because within the terms of discourse and power-there is nothing whatsoever simple about these performances. But, the idea of performance does create the possibility of subversive

3. Butler, Gender Trouble and Bodies that Matter, ibid.

4. Butler, Gender Trouble, ibid. at 140.

5. Ibid.

6. Butler, Bodies that Matter, ibid. 
performances, that is, of modes of doing gender that might disrupt and fragment the dominant cultural narrative.

A performative theory of gender that troubles the relationship between sex and gender helps us recognize the extent to which gender has become a category in crisis. Marjorie Garber has defined a category crisis as "a failure of definitional distinction, a borderline that becomes permeable, that permits of border crossings from one (apparently distinct) category to another." A performative theory understands sex and gender as precisely such categories, characterized by permeable borderlines that allows border crossings and transgressions, helping in turn to further destabilize these categories.

\section{The Performance of Gender in International Law}

The proliferating feminist scholarship and activism on international law has brought gender onto the international stage. Feminists have focused attention on the exclusion of women from international law, and insisted on the importance of incorporating gender analyses into the study and practice of international law. ${ }^{8}$ Although the results are uneven, feminists have made significant inroads in reshaping aspects of international law to better acknowledge the realities of women. However, to the extent that gender has been brought onto the international stage, it remains a noun, (or an adjective), not a verb. It is a category, not a performance. And as a category, it is decidedly not in crisis. To the extent that gender has been brought on stage, the discourse and practice of international law continue to deploy a traditional conception of sex and gender. In this section, I briefly consider three examples where international law has been at least somewhat receptive to feminist advocacy by acknowledging the specific needs of women: the special rapporteur on violence against women, gender mainstreaming in human rights, and the International Criminal Court. While each of these three examples can be seen to be deploying a somewhat different conception of gender, with the special rapporteur deploying the most expansive and the ICC the most restrictive, none of the three have deviated from a conception of gender as a self-evident category.

\section{(a) The International Criminal Court}

The inclusion of gender within the Rome Treaty establishing the International Criminal Court represents a stunningly narrow conception of gender. Article 7 of

7. Marjorie Garber, "The Occidental Tourist" in Andrew Parker, ed., Nationalisms and Sexualities (New York: Routledge, 1992) at 125.

8. See, e.g., Hilary Charlesworth, Christine Chinkin \& Shelley Wright, "Feminist Approaches to International Law" (1991) 85 Am. J. Int'l. L. 613; Hilary Charlesworth, "Alienating Oscar? Feminist Analysis of International Law" (1994) 25 Stud. in Transnat'1 Legal Pol'y 1; Karen Knop, "Re/Statements: Feminism and State Sovereignty in International Law" (1993) 3 Transnat'1 L. \& Contemp. Problems 293; Hilary Charlesworth \& Christine Chinkin, The Boundaries of International Law: A Feminist Analysis (Manchester, UK: Manchester University Press, 2000 and New York: Juris Publishing, 2000). On international human rights more specifically see Karen Engle, "International Human Rights and Feminism: When Discourses Meet" (1992) 13 Mich. J. Int'l L. 517. 
the Rome Statute defining crimes against humanity as including gender persecution specifically defines gender: According to Article 7(3):

For the purpose of this statute, it is understood that the term gender refers to the two sexes, male and female, within the context of society. The term gender does not indicate any meaning different from the above. ${ }^{9}$

The inclusion of gender was extremely controversial, with the conflation of sex and gender occurring at the behest of the Vatican and the Islamic states who were adamant that the term 'gender' not be used to include homosexuality. ${ }^{10}$ The conception of gender here is explicitly limited to the two biological sexes. It is not entirely clear that it is even intended to include the more typical understanding of gender as socially constructed roles and values, although that may be the intention of the words "within the context of society".

It is worth noting that the conservative states, with their explicitly anti-gay agenda, locked onto the concept of gender as potentially subversive. Notwithstanding the relatively narrow ways in which gender has been largely a euphemism for women, these conservative states were still concerned about the potential for a broader interpretation of gender that would include gay men and lesbians. It is also worth noting that one of the most significant acknowledgments of the gender within international law also represents the narrowest conception of it. As gender comes to be more instantiated and mainstreamed at the international, its meaning has become rather more rigid and fixed.

\section{(b) Gender mainstreaming-Gender as a euphemism for Women}

The United Nations has responded to the criticism of the exclusion and marginalization of women with the policy of 'gender mainstreaming'. "As Hilary Charlesworth and Christine Chinkin describe, "the process involves integrating concerns of gender into all the activities that are funded or undertaken by an

9. Rome Statute of the International Criminal Court, 17 July 1998, U.N. Doc. A/CONF. 183/9 at article 7(3).

10. Charlesworth \& Chinkin supra note 8. C. Steains, "Gender Issues in the Statute of the International Criminal Court" in R. Lee, ed., The International Criminal Court (The Hague: Kluwer Law International, 1999). This was not the first time that the use of the word "gender" was controversial on the international stage. At the preparatory meetings leading up to the Fourth World Conference on Women in Beijing, several countries objected to the use of the term gender in the Platform for Action. As Dianne Otto explains, "This objection was motivated by a desire to ensure that gender was not understood as socially constructed, and especially, to erase any suggestion that the Platform might be inclusive of homosexuals, bisexuals or transexuals" in "Holding Up Half the Sky, But for Whose Benefit?: A Critical Analysis of the Fourth World Conference on Women" (1996) 6 Australian Fem. L. J. 7 at 11. While the use of the word gender was retained, on the grounds that "there was no indication that any new meaning or connotation of the term, different from accepted prior usage was intended", (ibid. at 11 quoting Report of the Informal Contact Group on Gender, July 7, 1995, UN Doc A/Conf177/L.2 at para. 2(2)), conservative states nevertheless made their objections clear, recording that they defined gender "as referring only to male or female, as grounded in biological sexual identity.".

11. At the Vienna Conference on Human Rights in 1993, it was agreed that the human rights of women should form 'an integral part' of the United Nations human rights work. See the Vienna Declaration and Programme of Action, I, para. 18, II, para. 37. 
organization, and spreading responsibility for gender issues throughout the organization, through appropriate guidelines and training, so that they become an aspect of the routine work of all staff'. ${ }^{12}$ In this mainstreaming, gender has come to operate as a kind of euphemism for women, intended to get at the cultural and social construction of women's oppression. An example of this phenomenon can be seen in the way in which "gender" mainstreaming is being used within the human rights field. Consider the "Expert group meeting on the development of guidelines for the integration of gender perspectives into human rights activities and programmes" 1995 organized by the UN Centre for Human Rights \& UNIFEM, which outlines the principles for the incorporation of gender perspectives into the work of UN human rights bodies. In the report, sex and gender are defined according to the traditional story of biological and cultural categories.

The term 'gender' refers to the ways in which roles, attitudes, values and relationships regarding women and men are constructed by all societies all over the world. Therefore, while the sex of a person is determined by nature, the gender of that person is socially constructed. ${ }^{13}$

"Gender perspectives" are in turn defined as "those which bring to conscious awareness how the roles, attitudes and relationships of women and men function to the detriment of women, and suggest different ways of constructing them that are not based on inequality, domination, and exploitation of women." ${ }^{14}$ This understanding can be seen reflected in the particular ways in which so called "gender based analysis" is being incorporated into the work of the Office of the High Commission for Human Rights. It is a conception of gender that reflects, to a large extent, the way in which gender has been deployed in much feminist theory and advocacy in international human rights.

\section{(c) Special Rapporteur-Intersectional Gender Analysis}

The Special Rapporteur of the Commission on Human Rights on Violence Against Women has adopted one of the most expansive conceptions of gender within international law. In her report on Race, Gender and Violence Against Women, prepared for the 2001 World Conference Against Racism, Racial Discrimination, Xenophobia and Related Intolerance, Radhika Coomaraswamy argued for a gender analysis that is attentive to the multiple forms of discrimination that women experience. $^{15}$

12. Charlesworth \& Chinkin, supra note 8.

13. Report of the Expert Group Meeting on the Development of Guidelines For the Integration of Gender Perspectives into United Nations Human Rights Activities and Programmes, 52nd Sess., UN Doc. E/CN.4/1996/105 (Geneva, July 3-7, 1995, prepared for the Commission on Human Rights, 20 November 1995).

14. Ibid.

15. The Special Rapporteur of the Commission on Human Rights on Violence Against Women, Race, Gender and Violence Against Women, 3rd Sess., UN Doc. A/CONF.189/PC.3/5 (prepared for the World Conference Against Racism, Racial Discrimination, Xenophobia and Related Intolerance, Geneva, 30 July 1-August10, 2001, Preparatory Committee, 27 July 2001) [hereinafter Report of the Special Rapporteur]. 
There is a growing recognition that the failure to address the various 'differences' that characterize the problems of different groups of women can obscure or deny human rights protections to all women. Indeed, while it is true that all women are in some way subject to gender-discrimination, it is also true that other factors, relating to women's social identities, such as class, caste, race, colour, ethnicity, religion and national origin, are 'differences that make a difference' in the ways in which various groups of women experience discrimination. ${ }^{16}$

The Special Rapporteur wrote of the importance of developing an approach that is attentive to the particular ways in which gender intersects with other identities. An intersectional approach to discrimination attempts to capture the interaction between different forms of discrimination, addressing the way in which "racism, patriarchy, economic disadvantages and other discriminatory systems contribute to create layers of inequality". The Special Rapporteur argued that this idea of intersectionality must be adopted into a comprehensive gender analysis:

A comprehensive gender analysis requires examination of the effects of gender, the effects of race and the effects of gender and race factors combined on the form violations take, the context in which they occur, their consequences and the availability and accessibility of remedies to victims. ${ }^{17}$

The Special Rapporteur recommended, inter alia, that the United Nations should develop new methodologies for identifying and addressing multiple forms of discrimination, and should mainstream an intersectional analysis of various forms of discrimination, including gender and racial discrimination. ${ }^{18}$

In this report, the Special Rapporteur can be seen to be responding to the diversity critique that has insisted on the heterogeneity of women across racial, ethnic, class, cultural, sexual orientation and class axis. ${ }^{19}$ It is a critique that has brought the category of "women" more directly into crisis, and has undoubtedly troubled the category of gender from within. It is a critique that found a voice on the international stage at the Fourth United Nations World Conference on Women in Beijing in 1995. The Beijing Platform for Action ${ }^{20}$ as well as Beijing +5 both acknowledged

16. Ibid. at 7 .

17. Ibid. at 10 .

18. Ibid. at 51 .

19. See, e.g., Angela Harris, "Race and Essentialism in Feminist Legal Theory" (1990) 42 Stan. L. Rev. 581; Marlee Kline, "Race, Racism and Feminist Legal Theory" (1989) 12 Harv. Women's L. J. 115; Kimberle Crenshaw, "Demarginalizing the Intersection of Race and Sex: A Black Feminist Critique of Antidiscrimination Doctrine, Feminist Theory and Antiracist Politics" (1989) U. Chi. Legal Forum 139. This critique has been echoed within intemational feminist scholarship. See, e.g., Tracey Higgins, "Anti-Essentialism, Relativism and Human Rights" (1996) 19 Harv. Women's L. J. 89; Annie Bunting, "Theorizing Women's Cultural Diversity in Feminist International Human Rights Strategies" (1993) 20 J. L. \& Society 6; Karen Engle, "Female Subjects of Public International Law, Human Rights and the Exotic Other Female" (1992) 26 New Eng. L. Rev. 1509; Adrien Wing, Global Critical Race Feminism: an international reader (New York: New York University Press, 2000); Isabelle Gunning, "Arrogant Perception, World Travelling and Multicultural Feminism: the case of female genital surgeries" (1991) 23 Colum. Human Rights L. Rev. 189; Celina Romany, "Black Women and Gender Equality in a New South Africa: Human Rights Law and the Intersection of Race and Gender" (1996) 21 Brooklyn J. Int'l L. 857.

20. Beijing Platforn for Action, UN Doc. A/CONF.177/20, chap.I, resolution 1 (adopted at the Fourth World Conference on Women, 4-15 September 1995, Beijing). However, the recognition of 
the importance of addressing racism and the multiple forms of discrimination that women confront. More recently, the Commission on the Status of Women considered the issue of gender and other forms of discrimination, with a particular focus on racism, at its forty fifth-session in March 2001.

While this development is laudable-and light years ahead of the rest of international law-it is important to note that the destabilizing of the category of women does not extend to a destabilizing of the gender/sex story. Rather, the Report of the Special Rapporteur does not deviate from the gender/sex distinction, observing that "gender refers to the socially constructed roles of women and men ascribed to them on the basis of their sex". ${ }^{21}$ The category of gender has been critiqued from within, troubling the assumed homogeneity of the women. But the category of gender has not been critiqued from the outside, that is, the relationship between gender and sex remains untroubled.

\section{Feminist Rethinking of Gender Categories}

The Report of the Special Rapporteur on Violence Against Women captures some of the more sophisticated insights of feminist international scholarship, which has come to insist on anti-essentialist and/or intersectional perspectives to gender. ${ }^{22}$ The category of 'women' has been deconstructed in an attempt to better reflect the racial, cultural, religious and other forms of diversity, troubling the category of women, and concomitantly, the concept of gender from within. Some feminist scholarship has taken this troubling of 'women' a step further, and undertaken a rethinking of the meanings of these concepts and categories. Many feminist scholars interested in the possibilities of cross cultural feminist analysis in the international human rights arena have attempted to transcend the oppositions between universal categories of women on the one hand, and the paralysis of cultural relativism approach that insists only on the truth of the local, by developing more complex understandings of the culture. ${ }^{23}$ For example, Leslie Obiora's work on culture, gender and customary law, speaks of categories no longer fixed and rigid, but "contingent, fluid and negotiable". ${ }^{24}$ Dianne Otto's work has similarly brought a postmodern sensibility to the study of international law..$^{25}$ In her rethinking of universality as an ethical dialogue located between modern and poststructural knowledges, Otto argues for a more complicated understanding of the power and limitations of modern categories, including gender.

women's diversity was limited: all references to sexual orientation were removed from the Final Declaration. See Otto, supra note 10.

21. Report of the Special Rapporteur, supra note 15 at 4.

22. See supra note 15 . See also Charlesworth \& Chinkin, supra note 8.

23. See, e.g., Higgins, supra note 19; Arati Rao, "The Politics of Gender and Culture" in Julie Peters \& Andrea Wolper, eds., Women's Rights, Human Rights: International Feminist Perspectives (New York: Routledge, 1995); Nancy Kim, "Toward a Feminist Theory of Human Rights: Straddling the Fence Between Western Imperialism and Uncritical Absolutism" (1993) 25 Colum. Human Rights L. Rev. 49.

24. Leslie Amede Obiora, "Feminism, Globalization and Culture: After Beijing" (1997) 4 Ind. J. Global Legal Stud. 335 at ft. 152.

25. Dianne Otto, "Rethinking the Universality of Human Rights Laws" (1997) 29 Colum. Human Rights L. Rev. 1. 
...we need to acknowledge that categorical thinking enables us to communicate and to act. Without categories, classifications and comparisons, we are left with a world of infinite sui generis items and without a basis for making judgments of justice, ethics or rights. Yet categories also always exclude other possibilities by obscuring the multiple strands that make up the whole and the ways in which the strands interrelate. ${ }^{26}$

She argues that it is not a question of dispensing with the abstractions of categories, but rather, "of continually questioning which categories we use in human rights discourse and contesting the power that is attributed to them by modernity's dual construction of Standard and Other, or commensurability and erasure"..$^{.7}$

But, even within this profound and crucial troubling of gender, I would suggest that the category itself, and particularly, its relationship to the underlying categories of sex and sexuality, remain, categorically not in crisis. Gender continues to be understood as the social and cultural meaning given to the biological differences of sex. While sex and gender are related, they remain conceptually distinct categories, with sex operating as the natural, prediscursive category.

There are some recent exceptions, notably Hilary Charlesworth's recent work distinguishing between sex and gender analysis. ${ }^{28}$ Charlesworth notes that although feminist analysis has shown 'a preference for gender as a category of analysis', the category of sex might also provide a productive and insightful analysis of international law. ${ }^{29}$ Hilary Charlesworth and Christine Chinkin's recent work on feminist approaches to international law similarly acknowledges the critique of the sex/gender distinction. ${ }^{30}$ They observe the typical feminist deployment of gender as drawing attention "to those aspects of social relations that are culturally contingent and without foundation in biological necessity" and sex as referring to biological differences, "a fixed, immutable characteristic ... rather than a contestable category". Citing the work of Jane Flax, they note that "the separation of 'gender' and 'sex' in feminist inquiry rests on problematic and culture-specific oppositions such as nature/culture and body/mind."31

If we attend to the constitutive role of law and society in forming the 'naturally' sexed person, the concepts of 'sex' and 'biological difference' can be seen to have constructed, contingent and political elements. ${ }^{32}$

While accepting the critique of the constitutive nature of sex, Charlesworth and Chinkin go on to distinguish between the two concepts in focusing on different sides of the mind/body, culture/nature dichotomies: sex draws attention to body and nature, while gender draws attention to mind/culture. ${ }^{3.3}$ The subsequent analysis,

\footnotetext{
26. Ibid. at 27-28.

27. Ibid. 251.

29. Ibid. at 254 .

30. Charlesworth \& Chinkin, supra note 8.

31. Ibid.

32. Ibid.

33. Ibid.
}

28. See Hilary Charlesworth, "The Sex of the State in International Law" in Ngaire Naffine \& Rosemary Owens, eds., Sexing the Subject of Law (North Ryde, UK: Sweet \& Maxwell, 1997) 
although highlighting both the sexed and gendered assumptions that inform international law, does little to displace the dominant story of sex and gender.

Notwithstanding this more recent rethinking of feminist categories, by and large, the troubling of sex and gender, and crisis of categories that is found in so much contemporary feminist theory has not yet permeated feminist international law scholarship, let alone international law. The traditional relationship between sex and gender has not been troubled in the theatre of international law. Indeed, as gender comes to be instantiated at the international level, its meaning has become rather more rigid and fixed.

\section{Reperforming Gender as Outlaws}

What then, is wrong with such a fixed and rigid deployment of gender, if it allows the problems of women to become visible on the stage of international human rights? (admittedly, no small accomplishment). The problem lies in what this vision of gender naturalizes; in what remains invisible within this vision of gender. A fixed and rigid deployment of gender may allow some subjects to come on stage. But, the multiple other subjectivities constructed in and through gender remain beyond the margins, abject beings who are not yet the subjects of this discourse, who remain relegated to the zones of 'uninhabitability'. A methodological approach to gender as performance that disrupts the traditional relationship between sex and gender, while destabilizing both of these categories can open up a gendered analysis to a much broader array of identities and subjectivities. Gender, as a performance, introduces a range of marginalized subjects, beyond the subject of woman. It will allow us to tell a story of marginality that has not yet been told. It is a kind of space clearing gesture that may help make room at the margins for the fringe dwellers, those whose lives have been lived beyond the margins of the international arena: the queer subject, the drag queen, the bull dyke, the cross dresser, the transsexual, the transgendered, the sex worker, the S/M dominatrix. A methodological approach to gender as performance allows an opening up of the inquiry of gender to include these gender outlaws.

Admittedly, some of these subjects, particularly the gay and lesbian subjecthave for several years now begun to materialize on the international scene. ${ }^{34}$ But the international human rights scholarship and activism that has struggled to make these subjects visible suffers from many of the same limited understanding of sex, gender and sexual identity. Most of the work that addresses sexual minorities treats sexual identity as a self evident and innate characteristic. Much of the literature then focuses on the violence that has been done to these subjects-because of this innate characteristic. Even within the work that attempts to make the connection between these gender outlaws and gender identities, critiquing the rigid bi-polar

34. See, e.g., Debra DeLaet, “Don't Ask, Don't Tell: Where is the Protection Against Sexual Orientation in International Human Rights Law?" (1997) 7 L. \& Sexuality 31; James Wilets, "International Human Rights Law and Sexual Orientation" (1994) 18 Hastings Int'1 \& Comp. L. Rev. 1; Douglas Sanders, "Getting Gay and Lesbian Issues on the International Human Rights Agenda" (1996) 18 Human Rights Q. 67; Amnesty International Breaking the Silence (1994). 
construction of gender, gender and sex are still understood as conceptually distinct; with sex operating as biological designation, and gender the socially constructed roles. ${ }^{35}$

By way of contrast, a performative approach to gender that explores the subversive potential of these gender outlaws, that is, the particular ways in which these subjects challenge the dominant cultural narratives of sex, gender and heterosexual identity, may provide a different, and deeper set of insights into the opposition that these gender outlaws face. It is an approach that would recognize these gender outlaws not only as political allies of feminism, but as struggling against the very same restrictions on the performance of gender, within a heterosexual matrix that requires stable sexed bodies. For these are subjects whose gender performances each contain subversive possibilities; who perform gender dangerously, if not unambivalently. Queer subjects, transgendered subjects, empowered prostitute subjects, $\mathrm{s} / \mathrm{m}$ subjects. These are subjects whose gender performances are also simultaneously erotic performances, whose lives perform desire and fantasy, border crossing and gender treason. ${ }^{36}$

Inevitably, some will object that these are quintessentially Western identities, of little or no concern to the postcolonial subject. This objection is typically deployed as a delegitimizing move, intended to culturally triumph any discussion of these marginalized sexualities as decadent and western, as corrupting and corrosive influences of a westernized modernity. But, these gender outlaws, and their discursively produced erotically charged bodies are as cross cultural as their constituting categories of sex and gender. Examples abound of the existence of sexual minorities around the globe. In India, there is the new visibility of what Ratna Kapur has called the "postcolonial sexual subaltern", ranging from the gay men and lesbians who are challenging the sodomy provisions in the criminal code, to the sex workers organizing and demanding the right to practice their profession, calling upon their ancient history as courtesans, highly skilled practitioners of the arts who could command vast sums for their performances, to the Hhijras, a transgendered group with an ancient cultural heritage whose place in Indian popular culture has never been particularly controversial. ${ }^{37}$ In the Philippines, an organization called

35. See James Wilets, "Conceptualizing Private Violence Against Sex Minorities as Gendered Violence: International and Comparative Perspectives" (1997) 60 Albany L. Rev. 989, arguing that sexual minorities are gender outlaws. Sexual minorities, defined as "individuals who have traditionally been distinguished by their sexual orientation, inclination, behavior, or nonconformity with gender roles or identity" (ibid. at 990) are struggling against gender conformity and a "rigid bi-polar construction on gender" (ibid. at 1007). However, Wilets retains a traditional distinction between sex and gender, defining sex as "the biological designation of an individual as male or female (as genitally defined)" and gender as "the socially constructed roles of 'female', 'male' or combination thereof." (Ibid. at 990).

36. For a discussion of a performative gender approach to the issue of transgender, see Hasan Shafiqullah, "Shape-shifters, Masqueraders \& Subversives: An Argument for the Liberation of Transgendered Individuals" (1997) 8 Hastings Women's L. J. 195; for a discussion of a performative gender approach to the issue of sado-masochism, see Sangeetha Chandra-Shekeran, "Theorising the Limits of the 'Sadomasochistic Homosexual' Identity in R. v. Brown" (1997) 21 Melbourne U. L. Rev. 584.

37. See Ratna Kapur, "A love song to our Mongrel Selves" (1999) 8 Social and Legal Studies 353; "Law and the Sexual Subaltern: A Comparative Perspective" (2000) 48 Clev. State L. Rev. 15; "Exotic Disruptions: Legal Narratives on Nation, Sex and Culture in India" (2001) 10 Colum. J. L. \& Gender 333. 
the Progressive Organization of Gays (Progay), along with other human rights organizations, have mobilized against the introduction of a bill that will bar the recognition of marriage involving transgendered persons, contracted in the Philippines or abroad, and bar recognition of marriages or domestic partnerships between two people of the same biological sex. In order to specifically prevent the recognition of transgendered marriages, the family legislation which defines a marriage as a woman and man, will be reformed to read "natural born woman" and "natural born man". ${ }^{38}$ This lobbying effort has in turn resulted in a House Committee of the Philippines House of Commons approving in principle an anti-discrimination bill, written in collaboration with lesbian, gay and transgendered activists. ${ }^{39}$

Sexual performance is not owned by the West, nor necessarily by modernity although it has now been permanently re-figured in and through it. ${ }^{40} \mathrm{Just}$ as feminists have insisted that the analysis of gender must be cross cultural, with all its concomitant risks, and challenges that feminist scholarship has so productively explored, ${ }^{41}$ the destabilization of the category must also be cross cultural. Destabilizing the category of gender must be materially and historically specific, attentive to the hybridity of gendered subjects, produced through a myriad of local histories, subaltern struggles, and transnational cultural flows. It must displace the Anglo-American moorings of queer theorizing of sexual subjects, of these gender outlaws, and locate the analysis in a more postcolonial time and space. ${ }^{42}$

Opening up the inquiry to include a performative approach that explores the subversive potential of gender outlaws and their discursively produced erotically charged bodies can be productive for those interested in the question of the gender of international law, particularly as an exercise in marginality, of negotiating, mapping and remapping the margins of the international. ${ }^{43}$ These bodies, these gendered

38. Philippines House Bill 1503. See IGLHRC Action Alert, "Philippines: Proposed Marriage Legislation in Senate Discriminates Against Homosexuals and Transgenders", online: IGLHRC www.iglhrc.org/world/se_asia/philippines1999feb.html (February, 1999).

39. Philippines House Bill 2784. See IGLHRC, "House Committee Approves "In Principle" Lesbian, Gay, Bisexual and Transgender Anti-Discrimination Bill, online: IGLHRC www.iglhrc.org/ world/se_asia/philippines2001Dec_2.html.

40. Some queer theorists have begun to consider the impact of internationalization on gay and lesbian identity, noting in the words of Carl Stychin the "danger of colonization by an Anglo-American model of identity" in A Nation by Rights: National cultures, sexual identity politics, and the discourse of rights (Philadelphia, PA: Temple University Press, 1998) at 196. For a critical analysis of the impact of internationalization and globalization on gay identities, see Dennis Altman, "Rupture or Continuity: The internationalization of gay identities" (1996) 48 Social Text 77; Bob Cant, "Introduction" in Bob Cant, ed., Invented Identities: Lesbians and gay men talk about migration (London: Cassell, 1997) 1.

41. See, e.g., Uma Narayan, Dislocating Cultures: Identities, Traditions and Third World Feminism (New York: Routledge, 1997); Inderpal Grewal \& Caren Kaplan, eds., Scattered Hegemonies: Post Modernity and Transnational Feminist Practices (Minneapolis: University of Minnesota Press, 1994); Chandra Talpade Mohanty, "Feminist Encounters: Locating the Politics of Experience" in Michele Barrett \& Anne Phillips, eds., Destabilizing Theory: Contemporary Feminist Debates (Stanford, CA: Stanford University Press, 1992); Lata Mani, "Multiple Mediations: Feminist Scholarship in the Age of Multinational Reception" in Helen Crowley \& Susan Simmelweit, eds., Knowing Women: Feminism and Knowledge (Cambridge, UK: Polity Press, 1992).

42. Brenda Cossman, "Turning the Gaze Back on Itself: Comparative Law, Feminist Legal Studies and the Postcolonial Project" (1997) Utah L. Rev. 525.

43. See, e.g., David Kennedy, "The Disciplines of International Law and Policy" (1999) 12 Leiden J. Int'l L. 9, on new approaches to international law. 
performances, may provide new insight into the hegemonic character of international law. They might provide a new set of tools, icons, metaphors to explore the multiplicity of ways in which international law is in fact sexed and gendered. Just as feminist theory and the category of women have been deployed to both map and challenge the boundaries of international law, so too might these shadow dwellers further this project. These bodies may help us develop a deeper understanding of the international law, and its margins. ${ }^{44}$ Indeed, as a more rigid and fixed understanding of gender moves onto the stage of international law with the incorporation of women into its agenda, albeit in uneven and unfinished ways, these gender outlaws may assume greater salience in the ongoing project of negotiating, mapping and remapping the margins of the international.

There is also the more strategic question of what international law can do for these bodies. Here, I focus on the more specific terrain of international human rights, and consider some ways in which this terrain might be strategized and deployed to advance the struggles of these gender outlaws. Such an strategy might begin by simply putting these bodies on our normative map of international human rights, recognizing these bodies as rights bearing subjects.

But, such recognition would be no small feat. Rights recognition is a process of conferring discursive legitimacy; of bringing the body in from its state of abjection to reconstitute it as a subject, as a legitimate citizen. And these bodies, who perform desire, fantasy, border crossing and gender treason are outlaws. These bodies are seditious-not only to conservative states who violently oppose the mere utterance of things gay, but often, to some feminists and other progressive movements whose notions of harm and visions of equality often clash with the very idea of an empowered prostitute body or a legitimate S/M body engaged in erotic theatre of domination and submission. Rights recognition would require a fundamental reorientation of at least some feminist theorizing and advocacy that not only does not respect these bodies, but calls for their further regulation/repression. Moreover, these bodies are so deeply constituted by their positions of marginality and abjection, taboo and otherness, that the conferral of such legitimacy might risk destroying their very identity. ${ }^{45}$ The thrill lies, at least in part, in being off stage, in being provocative, in being, in the words of the law, lewd and lascivious. Normative recognition, then is both profoundly challenging for those already on stage, and not without its attendant risks for the bodies themselves.

44. See, e.g., Ed Morgan, "The Hermaphroditic Paradigm of International Law: A comment on Alvarez-Machain" (1992) Can. Council of Int'l Law Proc. 78, using the hermaphrodite as metaphor for the gendered nature of international law.

45. The question of the depoliticizing impact of assimilation is well trodden. In the context of women, feminists have questioned whether assimilation through the process of rights recognition would not force women into male centric models, values, and institutions, destroying the women's values, knowledge and ways of doing. In the context of gay liberation, queer theorists have questioned whether assimilation through rights recognition would force gay men and lesbians to abandon their subversive lifestyles, and adopt heterosexual models of family, sexuality and intimacy. See, e.g., Michael Warner, The Trouble with Nonnal: Sex, Politics and the Ethics of Queer Life (New York: Free Press, 1999); Lauren Berlant \& Michael Warner, "Sex in Public" (1998) 24 Critical Inquiry 547. In the context of pornography, scholars have argued that it is the very process of censoring and censuring that creates the object of the obscene. In each of these contexts, the location of the subjects at the margins is in some way constitutive of a subversive identity, a subversive identity that comes to have normative value in its own right. 
The struggle for the normative recognition of the rights of sexual minorities is not foreign to international human rights. Putting gender outlaws on the normative map includes joining with the efforts of those scholars and activists, who in recent years have struggled for this recognition in and through a range of human rights demands and strategies. ${ }^{46}$ These scholars and human rights activists take up the cases of the persecution of these gender outlaws, and trying to stop the harm that is routinely done to them. The International Gay and Lesbian Human Rights Commission lobbies for the repeal of sodomy laws, and brings international attention and support to individuals criminally charged with sodomy. ${ }^{47}$ For example, it, along with other human rights organizations have brought international attention to the detention of fifty-two men in Egypt in May 2001 because of their presumed homosexuality. The accused' cases were heard before the Emergency State Security Court in Cairo in November, and twenty-three men were sentenced to between one and five years of hard labour. ${ }^{48}$ Attention has similarly been brought to the police raid and criminal charges brought against two organizations in Lucknow, India, promoting sexual health among men who have sex with men. The police confiscated AIDS education material, and arrested the members of the staff, who have been charged with the possession of obscene materials and with conspiracy to commit sodomy ${ }^{49}$ These scholars and advocates similarly take up the cases of those sexual minorities from gays and lesbians and transgendered people to sex workers and HIV positive individuals who have suffered other forms of criminal prosecution, police harassment or violence in police custody.

But, in challenging this persecution, these bodies will not pose as the poster children of victims of sexualized violence; because these bodies, despite the harm that is done to them, are bodies that celebrate the pleasure of sex, desire, subversion, fantasy; because these are bodies whose identities are constituted in and through the instability and reverie of sex, sexuality and gender; because these gender outlaws insist on sex, sexuality and gender as always simultaneously a site of danger and pleasure, simultaneously a site of power and agency. And it is here that an engagement with these bodies may again be productive for feminists, some of whom are currently rethinking the disproportionate focus on women's

46. See Wilets, supra note 34. See also the work of the International Gay and Lesbian Human Rights Commission, which has advocated on behalf on sexual minorities, which it defines as "people whose rights are violated based on their real or perceived sexual practices with consenting adults or their experience or expression of their own gender." IGLHRC "Sexual Minorities and the Work of the United Nations Special Rapporteur on Torture", a paper submitted by the International Gay and Lesbian Human Rights Commission to Sir Nigel Rodley, Special Rapporteur on Torture, June 5, 2001. Online: IGLHRC www.iglhrc.org/issues/UN/UN_Torture2001Jun.html

47. See Wilets supra note 34, and the publications and alerts of the International Gay and Lesbian Human Rights Commission (IGLHRC), e.g., IGLHRC, "Sodomy Fact Sheet: A Global Overview: Criminalization and Decriminalization of Homosexual Acts", online: IGLHRC www.iglhrc.org/ news/factsheets/sodomy.html.

48. IGLHRC Action Alerts, "23 Presumed Homosexuals Sentenced to Hard Labour", online: IGLHRC www.iglhrc.org/world/africa/egypt2001nov_2.html (November 14, 2001). Egyptian law does not specifically criminalize homosexuality, so the men were charged with the offences of "obscene behavior" and "contempt for religion".

49. IGLHRC Action Alert, "Demand the Immediate Release of HIV/AIDS Prevention Workers Detained Under Sodomy and Obscenity Laws", online: IGLHRC www.iglhrc.org/world//s_asia/ India2001Jul_2.html. 
victimization. ${ }^{50}$ Rethinking the tightly regulated category of gender involves a recognition that gender performances are complex and stylized repetitions of acts, in which a subject's agency is "produced in and as a gendered matrix of relations". Rethinking gender involves an engagement with both the limits and possibilities of agency, including sexual agency. On the international stage, however, the focus remains overwhelmingly on sexual domination-on women as sexual victims. ${ }^{51}$ Opening up the inquiry of international scholarship on gender to include a performative approach that explores the subversive potential of gender outlaws may also be productive, then, in challenging this focus on sexual victimization.

A performative approach might also facilitate a shift away from identity based approaches in international human rights scholarship and activism. Drawing on the work of John D'Emilio, Kristen Walker has argued, in the context of gay and lesbian rights, for a shift from an approach that focuses on non-discrimination on the basis of sexual orientation to one that emphasizes sexual self-determination. ${ }^{52}$ With its roots in the theories of sexual liberation, sexual self-determination would seek to protect the diversity of sexualities and the right to sexual expression. As Walker imagines, "sexual self-determination is not just about freedom and equality... it is about valuing sexual diversity". ${ }^{53}$ Instead of simply focusing on rights accorded to identity categories, such as the rights of women to reproductive freedom or the rights of gays and lesbians to non-discrimination, the broader concept of sexual self-determination could protect these rights within a framework of enhancing the freedom of sexual subjects. A performative approach to gender would facilitate this shift from identity to sexual self-determination by emphasizing sexuality is something we do, not simply something we have. And an approach that emphasized sexual self-determination would in turn help to open up the inquiry into the performative bodies of gender outlaws. The right to sexual self-determination would bring on stage the sexual and gender practices of gender outlaws. It would include an affirmation of non-normative sexualities, that is, of the empowered sex worker, of the S/M dominatrix, of the transgendered lesbian, and the drag queen.

\section{Conclusion}

Let me come back in conclusion to where I began - to the gender performances in Shakespeare in Love, which I would recast as gender performance "lite". It is a kind of low-fat performance, with no serious health risks to the underlying categories of sex and sexuality. For the gender performance in Shakespeare in Love never fundamentally destabilized the underlying heterosexual desire- the bodies

50. See, e.g., Kathryn Francke, "Theorizing Yes: An Essay on Feminism, Law and Desire" (2001) 101 Colum. L. Rev. 181; Kathryn Abrams, "From Autonomy to Agency: Feminist Perspectives on Self Direction" (1999) 40 William \& Mary L. Rev. 801; Kathryn Abrams, "Sex Wars Redux: Agency and Coercion in Feminist Legal Theory" (1995) 95 Colum. L. Rev. 304.

51. See Ratna Kapur, "Tragedy of Victimization Rhetoric: Resurrecting the 'Native' Subject in International/Post-colonial Feminist Legal Politics" Harv. Human Rights J. [forthcoming in 2002].

52. Kristen Walker, "Capitalism, Gay Identity and International Human Rights Law" (American Society of International Law, Annual Meeting, Washington D.C. March 1999) [unpublished].

53. Ibid. at 8 . 
in love are, after all, the 'right' bodies-once undressed, one male, one female. And the Viola of Shakespeare in Love turns out not be the cross-dressing Viola of Twelfth Night, but the cross-dressing Rosalind of As You Like It, who returns to the stage dressed as a woman. Viola, like Rosalind, who having completed her education/acting/love affair, is now restored to her "rightful place", can now take up her wifely role, vanishing to the colonies, gender and class status recuperated. ${ }^{54}$

The performance of Viola, like Rosalind, then turns out to be farcical, like most silver screen representations of cross-dressing-from Victor/Victoria to Mrs. Doubtfire to Tootsie, the performance of gender never really troubles the categories of sex and sexuality. It does very little as a space clearing gesture for the marginal sexual subject. It is the kind of performance that international law might condone-an amusing aside, with no fundamental challenge to the fixed and rigid concept of gender that is being reluctantly and unevenly acknowledged within international law.

What the gender outlaws needs is a more seditious and subversive gender performance. Instead of Viola from Shakespeare in Love, the gender outlaw needs a performance more akin to those of Song Liling and Rene Gallimard in $M$. Butterfly. ${ }^{5 s} \mathrm{It}$ is a performance within a performance, a performance of gender, culture, nation and theatre. ${ }^{56}$ Song, a star of the Chinese opera, performs as a woman in her 20 year affair with the French diplomat, Gallimard. Gallimard, oblivious to the fact that female roles are played by men in Chinese opera, falls in love with this fantasy, his Butterfly, a fantasy of the East from the eyes of the West, a fantasy of femininity from the eyes of a man. And the performances, simultaneously real and fantastical, bring the categories of gender and culture, sexuality and nation, into crisis. Gender is shown to be as fantastical as the opera roles. As Song Liling asks and answers: "Why, in Peking Opera, are all women's roles played by men?....Because only a man knows how a woman is supposed to act."' And as Gallimard says at the end of the play, "I was a man in love with a woman created by a man, and now everything else simply falls short". The performance of East/ West, of Orientalism, and the homogenization and feminization of Asian cultures in the eyes of the West is similarly intended to bring these categories into crisis.

54. Marjorie Garber asks "Why is it so often Rosalind who is singled out as the exemplary early modern cross-dresser, the Katherine Hepbum (if not the Marlene Dietrich or the Annie Lennox) of her time?" (supra note 1 at 73). In her view: "Rosalind differs from Viola in a crucial way: she returns to the stage dressed as a women.... But in returning dressed as a woman she also allows for the possibility of a recuperative interpretation that suggests a transformed woman now "reabsorbed" into the community and thus capable of 'vanishing'. Rosalind, according to this recuperative fantasy, has finished her job of education and self education and can now take up her wifely role." (Ibid. at 76-77)

55. David Henry Hwang, M. Butterfly (New York: New American Library, 1989). The play is based loosely on the international spy scandal in which a French diplomat had a 20 year affair with a Chinese opera singer who he believed to be a woman. Boursicot was accused of passing information to China, and both Boursicot and Shi were sentenced to six years imprisonment.

56. See Kathryn Remen, "The Theatre of Punishment: David Henry Hwang's M. Butterfly and Michel Foucault's Discipline and Punish" (1994) 37 Mod. Drama 391; Robert Skloot, "Breaking the Butterfly: The Politics of David Henry Hwang" (1990) 33 Mod. Drama 59; John Louis DiGaetani, "M. Butterfly: An Interview with David Henry Hwang" (1989) 33 The Drama Rev. 141; Marjorie Garber, supra note 1.

57. Supra note 54 at 63 
When asked by the French judge how she could have fooled Gallimard for so long, Song Liling replies: "One because when he finally met his fantasy woman he wanted more than anything to believe that she was, in fact, a woman. And second, I am an Oriental. And being an Oriental, I could never be completely a man."

In the final scene, yet another gender performance unfolds, as Gallimard transforms himself on stage into the fantasy of Butterfly, dressing in the kimono and wig Song Liling has discarded on stage as she now performs herself as a man. To the music from the Death Scene in Madama Butterfly, Gallimard, now in the role of the Butterfly, commits suicide, while Song Liling watches on, recognizing only at that moment that she/he too has lost. The play is a tale of gender and national treason, of passing and of border crossings. It is a tale in which the categories of male and female, East and West, are called into crisis on multiple levels. And it is a tale that better captures the performative approach to gender that the marginal sexual bodies need to be brought on the international stage. Unlike Shakespeare in Love, the bodies in love are not the 'right bodies' of a heterosexual matrix. Nor do these bodies embody a simply homosexual matrix. These bodies are transformed and transformative, their "real" sex elusive and illusory. In M. Butterfly, gender is not who we are, but what we do. And yet, it is not a tale of sexual self-determination, but rather it is a tragic one, one in which the treason of these bodies is punished. Unlike the happy ever after ending of Shakespeare in Love, it is a tale that warns of the dire consequences for these bodies of a failure to transform the rigidities of gender on the international stage. 